\title{
Increased growth of Araucaria angustifolia under warm conditions is unaccompanied by increased photosynthetic performance
}

\author{
${\text { Lorena Egidio de } \text { Castro }^{1} \text { - Camila Kissmann }}^{2}$ - Gustavo Habermann ${ }^{3}$
}

Received: 3 September 2016/Accepted: 11 April 2017/Published online: 22 April 2017

(C) Springer-Verlag Berlin Heidelberg 2017

\begin{abstract}
Key message Although A. angustifolia occurs in regions with subtropical climate, warm conditions do not seem to impair the growth of young plants.

Abstract The effects of increasing temperature are worth studying even in tree species from subtropical climates. Araucaria angustifolia occurs in the south and southeast of Brazil and in Argentina and its growth and success may be associated with low temperatures. We measured growth, photosynthetic parameters and the nutritional status of this plant growing under artificial warm and cool conditions. We expected growth and photosynthetic performance to increase under cool rather than warm conditions. Under high daily temperature, plants showed increased leaf area per plant, more leaves, containing more nitrogen. However, $\mathrm{CO}_{2}$ assimilation rates at light saturation were similar in
\end{abstract}

Communicated by T. Grams.

Electronic supplementary material The online version of this article (doi:10.1007/s00468-017-1553-3) contains supplementary material, which is available to authorized users.

Gustavo Habermann

ghaber@rc.unesp.br

1 Programa de Pós-Graduação em Biologia Vegetal, Departamento de Botânica, Instituto de Biociências, Universidade Estadual Paulista (UNESP), Av. 24-A, 1515, Rio Claro, SP 13506-900, Brazil

2 Departamento de Botânica, Instituto de Biociências, Universidade Estadual Paulista (UNESP), Rua Prof. Dr. Antonio Celso Wagner Zanin s/n, Botucatu, SP 18618-689, Brazil

3 Departamento de Botânica, Instituto de Biociências, Universidade Estadual Paulista (UNESP), Av. 24-A, 1515, Rio Claro, SP 13506-900, Brazil plants grown under both conditions, and photosynthetic nitrogen use efficiency was $25 \%$ higher in plants under cool conditions. This may be the first report of temperature effects on the growth of this species. Despite enhancing growth in A. angustifolia, warm conditions do not directly influence photosynthetic activities, but enhance leaf area per plant allowing increased $\mathrm{CO}_{2}$ uptake.

Keywords Brazilian pine - Ecophysiological responses · Gas exchange $\cdot$ Temperature

\section{Introduction}

In general, plants grow more under warm conditions than under cool conditions. Plant growth (increase in plant size, leaf area and biomass), as a result of temperature, is dependent on thermal sensitivity of growth (Atkin et al. 2006), acclimation of respiration (Atkin et al. 2005), optimal temperature for photosynthesis (Berry and Bjorkman 1980) and, an interaction of the above-mentioned processes influences the carbon balance. Under warm conditions or when temperature rises, plants exhibit enhanced growth and increased photosynthesis (Hikosaka et al. 2006; Ribeiro et al. 2012), as the optimal temperature for photosynthesis increases due to changes in activation energy of enzymes involved in these processes (Hikosaka et al. 2006).

However, some species are adapted to cool conditions. For example, Eucalyptus globulus shows increased photosynthetic rates under cool conditions (Costa e Silva et al. 2009), as its genetic center of origin is believed to be in Tasmania, contrasting to its congeneric $E$. grandis, adapted to warm conditions. Gymnosperms are also adapted to temperate climates and, under cool conditions, are 
expected to have an advantage at some biological/ecological level (Arroyo et al. 1996). Larix decidua and Pinus mugo, two conifer species from montane provenances in Switzerland, show biomass production even at $6{ }^{\circ} \mathrm{C}$ (Hoch and Körner 2009), indicating that plants adapted to temperate climates maintain their growth capacity under conditions in which most plants would stop growing. These authors support that conifers do not deplete their carbon resources (photosynthetic activity), although extremely low temperatures may affect their meristematic processes (sink activity).

There is much debate over the negative effects of increasing temperature on reproduction, growth and yields of plants that already are at their top limit responses to increasing temperature, especially of crop species with a $\mathrm{C}_{3}$ photosynthetic metabolism (Sage and Kubien 2007). On the other hand, studies discussing the effects of increasing temperature on the physiology of native plants adapted to cool or subtropical climates are less frequent (Saxe et al. 2001; Crawford 2008). Therefore, understanding the responses of plants from subtropical climate is important to predict whether these native populations are likely to expand or reduce the area of their natural occurrence in the case of a rise in temperature above average growing temperature for each species.

Models predict that a $3{ }^{\circ} \mathrm{C}$ increase in the current temperature could reduce the occurrence of Araucaria angustifolia (Brazilian pine) in its endemic region in South America (Wrege et al. 2009). This species occurs in the south and southeast of Brazil and in Argentina (Reis et al. 2014). In Brazil, the distribution of A. angustifolia seems to exhibit an inverse relationship between latitude and altitude, so that in latitudes around $20^{\circ} \mathrm{S}$ it occurs at $1500-1800 \mathrm{~m}$ of altitude, while between $25^{\circ} \mathrm{S}$ and $30^{\circ} \mathrm{S}$ it occurs at $500-900 \mathrm{~m}$ of altitude (Ledru and Stevenson 2012), indicating that this distribution pattern could be associated with cool and moist conditions of subtropical climate. In fact, a negative correlation between temperature and growth of male individuals of $A$. angustifolia, which grew more during the cold than in the warm season, has already been observed (Cattaneo et al. 2013). This indicates that cool conditions may benefit this species at some level.

There are no studies determining the average growing temperature for A. angustifolia. Few ecophysiological studies have been conducted with this species, focusing on its response to contrasting irradiance (Duarte and Dillenburg 2000), soil compaction, water relations (Mósena and Dillenburg 2004; Cassana and Dillenburg 2013; Cassana et al. 2015), as well as comparisons between young and adult trees in the field (Franco et al. 2005). Studies about the effects of increasing temperature on the physiology of A. angustifolia are important, even though this species is associated with cool and moist conditions of subtropical climate. Indeed, no evidence has been collected on how $A$. angustifolia may react to a rise in temperature, or even to any contrasting temperatures. This lack of evidence may be due to the fact that the above-mentioned studies with this species concentrate on issues not related to identifying the best temperature for seedling production and reforestation, for example.

Under this perspective, we evaluated growth, photosynthetic parameters and nutritional status of $A$. angustifolia seedlings grown under two contrasting artificial daily temperatures (warm and cool conditions). Given the natural occurrence and observations made in the field for this species, we expected that growth and photosynthetic performance to increase under cool rather than warm conditions.

\section{Materials and methods}

\section{Plant material}

Plants of Araucaria angustifolia (Bertol.) Kuntze (Araucariaceae) measuring $47 \pm 5.9 \mathrm{~cm}$ in height and with an age of 1.5 years were used. These plants were obtained from germinated seeds ('pinhão' as they are also called in local communities) collected at the municipality of Pilar do Sul, state of São Paulo, Brazil ( $23^{\circ} 48^{\prime} 37^{\prime \prime}$ S, $47^{\circ} 42^{\prime} 48^{\prime \prime}$ W) in April 2014. The leaves of this plant species are like a short-base (approximately $0.5 \mathrm{~cm}$ ) isosceles triangle exhibiting $3-4 \mathrm{~cm}$ in length, a typical triangular-lanceolate leaf described for some gymnosperms, and its thickness averages $1 \mathrm{~mm}$. Therefore, these are not needles, but leaves.

A substrate made of oxisoil:organic substrate:sand (2:2:1 v:v:v) was prepared together and distributed to individual pots $(10 \mathrm{~L})$ where the plants grew and were irrigated every other day. The pots were kept on benches in a greenhouse with semi-controlled conditions for five months before separating the groups of plants for the study.

\section{Study design and experimental conditions}

One group of 12 plants was maintained under warm conditions while another group of 12 plants was maintained under cool conditions for 120 days. The warm conditions were created using a plastic cover applied over a bamboo structure placed on a bench $(3 \mathrm{~m} \times 1 \mathrm{~m} \times 0.80 \mathrm{~m})$ inside a greenhouse. This structure simulated a small greenhouse ( $3 \mathrm{~m}$ in length, $1 \mathrm{~m}$ in width and $1 \mathrm{~m}$ in height above the bench) (Fig. 1c). The cool conditions were created using a plastic cover applied over a cubic structure made of aluminum frames placed on a bench inside the greenhouse. 
Fig. 1 Structure (a) and attached air conditioner (b) for simulation of cool conditions and respective structure for simulations of warm conditions (c)

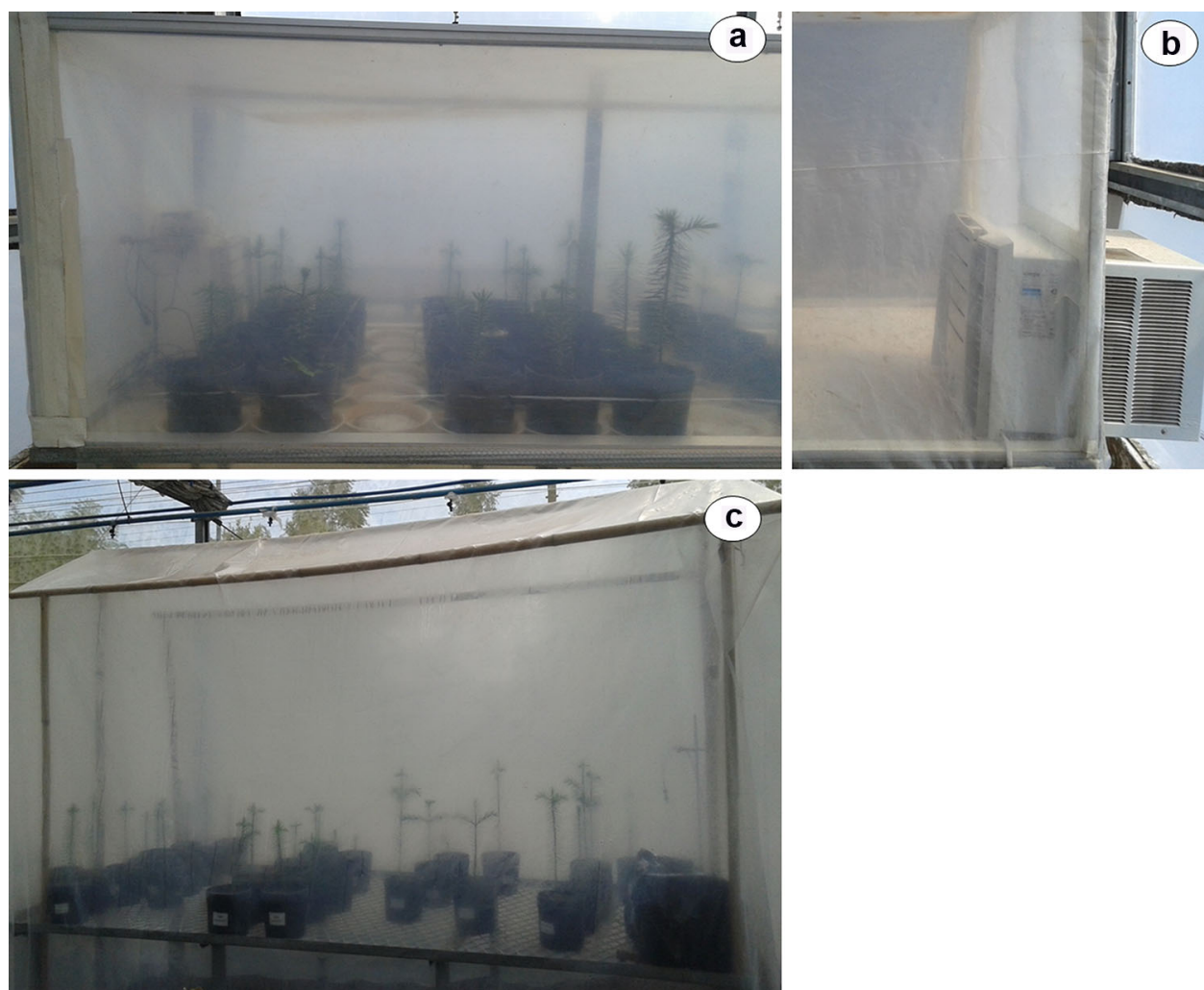

This cubic structure was $3 \mathrm{~m}$ in length, $1 \mathrm{~m}$ in width and $1 \mathrm{~m}$ in height (Fig. 1a), and it had a small window $(0.45 \times 0.32 \mathrm{~m})$ where an air conditioner (Springer, Porto Alegre, Brasil) was placed to provide cooler air than that inside the greenhouse (Fig. 1b). Air temperature $\left({ }^{\circ} \mathrm{C}\right)$ and photosynthetic photon flux density (PPFD; $\mu \mathrm{mol} \mathrm{m} \mathrm{m}^{-2} \mathrm{~s}^{-1}$ ) were measured inside both structures using a 1400-101 air temperature sensor (LI-COR, Lincoln, NE, USA) and a LI190-SA quantum sensor (LI-COR, USA), respectively. Under each condition, these sensors were connected to a data logger (LI-1400, LI-COR, USA) that collected data every $30 \mathrm{~min}$ on a daily basis.

Daily amplitude in air temperature was larger under warm conditions $\left(14.5^{\circ} \mathrm{C}\right)$ when compared to cool conditions $\left(3.3{ }^{\circ} \mathrm{C}\right)$. Under warm conditions, the temperature varied from $19{ }^{\circ} \mathrm{C}(3: 00-6: 00 \mathrm{~h})$ to $33{ }^{\circ} \mathrm{C}(12: 00-14: 00 \mathrm{~h})$, while under cool conditions it only varied from $17.5{ }^{\circ} \mathrm{C}$ (3:00-6:00 h) to $20.8{ }^{\circ} \mathrm{C}(15: 00 \mathrm{~h})$ (Fig. 2a).

Using plants growing in both conditions, we measured plant height, number of new shoots, root-collar diameter, gains in shoot length, root-collar diameter and number of new shoots $(n=12)$ as well as leaf gas exchange rates at $30,60,90$ and 120 days $(n=6)$. At 120 days of study, we measured root length, root volume, number of leaves per plant, total leaf area per plant, and the biomass of roots, shoots, leaves and total biomass $(n=5)$. At 120 days of study, we also measured the photosynthetic nitrogen use efficiency (PNUE), as well as total contents of nitrogen $(\mathrm{N})$, phosphorus $(\mathrm{P})$, potassium $(\mathrm{K})$, calcium $(\mathrm{Ca})$, magnesium $(\mathrm{Mg})$ and sulfur $(\mathrm{S})$ in the roots, shoots and leaves $(n=3)$. Soil fertility parameters of the substrate used in the pots of plants grown under both conditions were also assessed $(n=3)$.

\section{Soil fertility}

At the end of the study, soil samples were randomly collected from five pots from both warm and cool conditions. These samples were taken to the Soil Science Lab at University of São Paulo (USP, Esalq), in Piracicaba, SP, Brazil for routine soil chemical (fertility) analysis $(\mathrm{pH}$ in $\mathrm{CaCl}_{2}$ ), which was performed according to van Raij et al. (2001), and the procedures are described in English by Dantas and Batalha (2011).

\section{Biometric parameters}

Plant height was measured with a ruler $(\mathrm{cm})$, root-collar diameter with digital calipers $(\mathrm{mm})$ and the number of new shoots (emitted since the beginning of the study) was counted. The gains in the shoot length, root-collar diameter and number of new shoots considered the increase in the length, diameter and number of these parameters since the start of treatment application. At the end of the study, root 


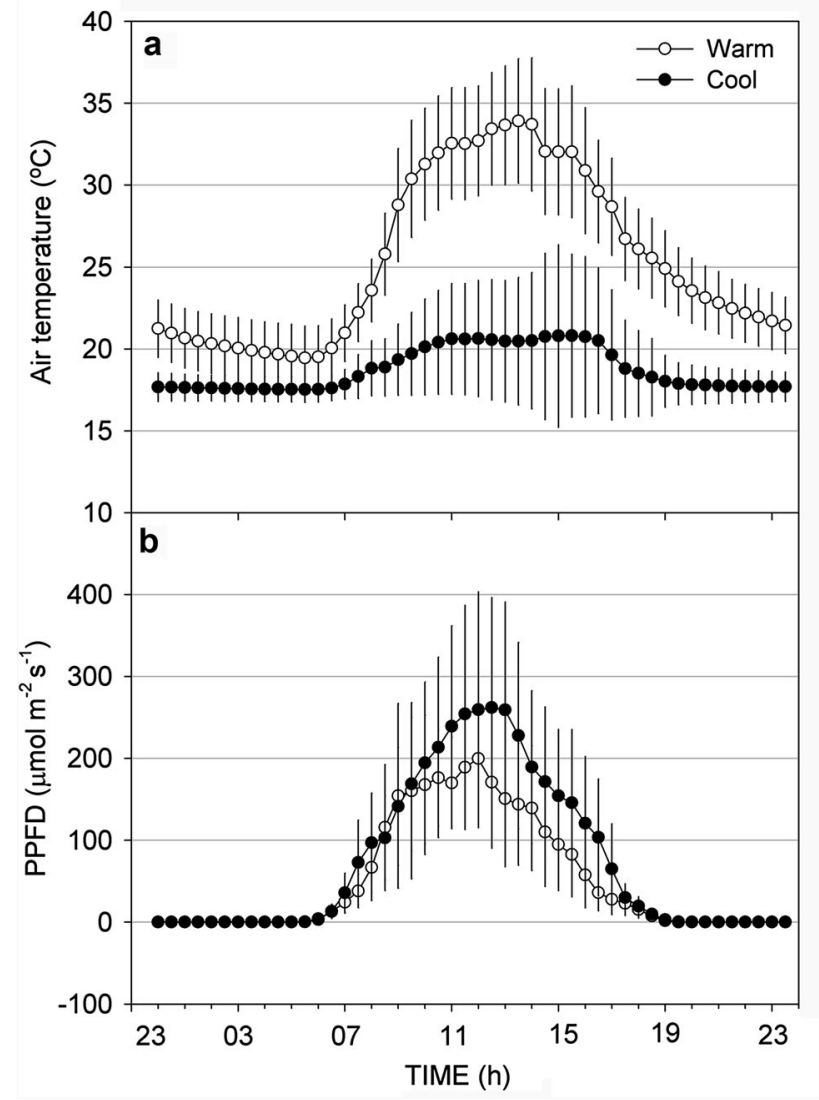

Fig. 2 Daily oscillation in the air temperature (a) and photosynthetic photon flux density (b) measured inside the warm and cool conditions structures. The data were collected during 120 days on a daily basis at every $30 \mathrm{~min}$. Vertical bars SD

length was measured with a ruler $(\mathrm{cm})$, and root volume assessed by water dislocation when excised root systems of plants were inserted into a graduated cylinder $(\mathrm{mL})$. At 120 days of experiment, all the leaves of each of the five replications were excised and counted and total leaf area per plant $\left(\mathrm{cm}^{2}\right)$ was measured with an area meter (LI3100C, LI-COR, USA). Subsequently, leaves, shoots and roots of the whole plant of each of the five replications were placed in paper bags and dried at $60{ }^{\circ} \mathrm{C}$ (to avoid $\mathrm{N}$ volatilization) until constant mass. The biomasses ( $\mathrm{g}$ ) of organs were assessed with an analytical scale.

\section{Plant nutritional status}

After assessing the biomasses of organs, three (already dry) samples of leaves, shoots and roots were ground and digested in a nitric-perchloric acids solution. Potassium concentration was determined in a flame photometer (Micronal B262, Micronal, São Paulo, Brazil). Calcium and $\mathrm{Mg}$ were determined by the atomic absorption spectrophotometer method. Phosphorus was quantified colorimetrically, $\mathrm{S}$ was determined using a turbidimetric method and $\mathrm{N}$ was measured by the micro-Kjeldahl method, all of which followed Sarruge and Haag (1974) and Dantas and Batalha (2011), and was performed in the routine Plant Nutrition Lab (Esalq, Usp, Piracicaba, SP, Brazil).

\section{Leaf gas exchange}

$\mathrm{CO}_{2}$ assimilation $\left(A, \mu \mathrm{mol} \mathrm{m}{ }^{-2} \mathrm{~s}^{-1}\right)$ and transpiration $(E$, mmol m$\left.{ }^{-2} \mathrm{~s}^{-1}\right)$ rates, stomatal conductance $\left(g s, \mathrm{~mol} \mathrm{~m}^{-2}\right.$ $\left.\mathrm{s}^{-1}\right)$, and intercellular $\mathrm{CO}_{2}$ concentration $\left(\mathrm{Ci}, \mu \mathrm{mol} \mathrm{mol}{ }^{-1}\right)$ were assessed in fully expanded triangular-lanceolate leaves with an open portable gas exchange system (LI6400xt, LI-COR, Lincoln, NE, USA). Water use efficiency (WUE, $A / E$ ) and intrinsic water use efficiency (IWUE, $A$ / $g s)$ were also calculated. Photosynthetic nitrogen use efficiency (PNUE, $\mu \mathrm{mol} \mathrm{CO} \mathrm{CO}_{2} \mathrm{~g}^{-1} \mathrm{~N} \mathrm{~s}^{-1}$ ) was calculated by the ratio between $A$ (transformed to $\mu \mathrm{mol} \mathrm{CO}_{2} \mathrm{~g}^{-1}$ leaf $\mathrm{s}^{-1}$ ) and leaf $\mathrm{N}$ content ( $\mathrm{g} \mathrm{N}$ per $\mathrm{g}$ dry leaves). One leaf per measurement was accommodated within the leaf chamber (6400-40 LCF, LI-COR) and measurements were performed between 9:00 and 11:00 $\mathrm{h}$ on cloudless days. The leaf area used to calculate gas exchange was the average from 15 leaves when disposed within the inner rubber ring, resulting in $0.7 \mathrm{~cm}^{2}$. The PPFD was provided by a red (90\%) and blue (10\%) LED light source (6400-02B led light source, LI-COR, USA), on top of the leaf chamber, set to provide $1200 \mu \mathrm{mol} \mathrm{m} \mathrm{m}^{-2} \mathrm{~s}^{-1}$, as this value returned saturating $A$ for $A$. angustifolia observed in a previous study (data not shown). $\mathrm{CO}_{2}$ concentration in the leaf chamber averaged $400 \mu \mathrm{mol} \mathrm{mol}^{-1}$, as provided by the 6400-01 $\mathrm{CO}_{2}$ mixer (LI-COR, USA). Vapor pressure deficit (VPD; $\mathrm{kPa}$ ), relative humidity (RH) and air temperature inside the leaf chamber were not set artificially, but oscillated with the external environment. Under warm conditions, VPD was $3.17 \pm 0.72 \mathrm{kPa}, \mathrm{RH} 47.8 \pm 7.3 \%$ and air temperature $34.0 \pm 2.2{ }^{\circ} \mathrm{C}$, while under cool conditions VPD was $2.62 \pm 1.53$, RH was $50.3 \pm 4.9$ and air temperature was $26.8 \pm 2.5^{\circ} \mathrm{C}$.

\section{Data analysis}

A Student t test $(\alpha=0.05)$ was performed (after checking for normal data distribution and homogeneous variance of data) between plants cultivated in warm and cool conditions, testing gas exchange variables $(A, g s, E, C i$, WUE, IWUE) $(n=6)$ and non-destructive parameters (gains in shoot length, root-collar diameter and number of shoots) at $30,60,90$ and 120 days of experiment $(n=12)$. Notwithstanding, we also run an analysis of variance (twoway Anova) to check gas exchange data between treatments over time, especially for $\mathrm{CO}_{2}$ assimilation rates that could result in some consequences for explaining the plant biomass. For this, time was used as one of the factors (four 
levels-30, 60, 90 and 120 days of experiment) and temperature as the other factor (two levels).

Using five replications for biometric parameters (number of leaves, shoot and root lengths, root volume, total leaf area per plant and biomass of organs) and three replications for PNUE, macronutrient contents in leaves, shoots and roots, we also used a Student t test $(\alpha=0.05)$ to test these variables at 120 days of experiment. Statistical tests were performed using SigmaPlot 12.0 Software, and standard deviation (SD) is given in all figures and tables.

\section{Results}

The results of soil fertility were similar for plants growing under warm and cool conditions (Table 1). However, plants under warm conditions showed $42 \%$ higher leaf $\mathrm{N}$ content when compared to those under cool conditions (Table 2). Leaf S content was also higher $(+13 \%)$ in plants under warm conditions when compared to those under cool conditions (Table 2).

Daily variations in PPFD under warm conditions were very close to daily variations in PPFD under cool conditions. At 12:00 h, average PPFD under warm conditions was $205 \mu \mathrm{mol} \mathrm{m} \mathrm{m}^{-2} \mathrm{~s}^{-1}$, while under cool conditions, it averaged $272 \mu \mathrm{mol} \mathrm{m}{ }^{-2} \mathrm{~s}^{-1}$ (Fig. 2b).

$\mathrm{CO}_{2}$ assimilation (Fig. 3a) and transpiration (Fig. 3b) rates were the same for plants under both conditions measured on every evaluating day when using the Student $t$ test. When a two-way Anova was used to check differences between treatments over time, it was shown that time exerted effects on $A$, but no significant interaction (time $\times$ temperature) was observed (Table 3).

Stomatal conductance $(\mathrm{gs})$ and intracellular $\mathrm{CO}_{2}(\mathrm{Ci})$ were higher for plants grown under cool conditions at 30, 60 and 90 days. Water use efficiency (Fig. 3d) and IWUE (Fig. 3f) showed a great variability, but WUE was higher in plants grown under warm conditions when compared to those under cool conditions only at 30 days of experiment, while for IWUE, higher values for plants under warm conditions occurred at 30 and 90 days of experiment.

The root length (Fig. 4b) and root volume (Fig. 4d) did not differ between plants grown under both conditions. However, the shoot length was 33\% greater in plants under warm conditions when compared to those under cool conditions (Fig. 4a). The number of leaves was $40 \%$ greater in plants under warm conditions when compared to those under cool conditions (Fig. 4c), and leaf area per plant was $30 \%$ larger in plants under warm conditions (Fig. 4f). On the other hand, the biomass of roots, shoots and leaves was the same in both treatments, being only slightly higher in plants under warm conditions when the total biomass was compared between treatments (Fig. 4e).

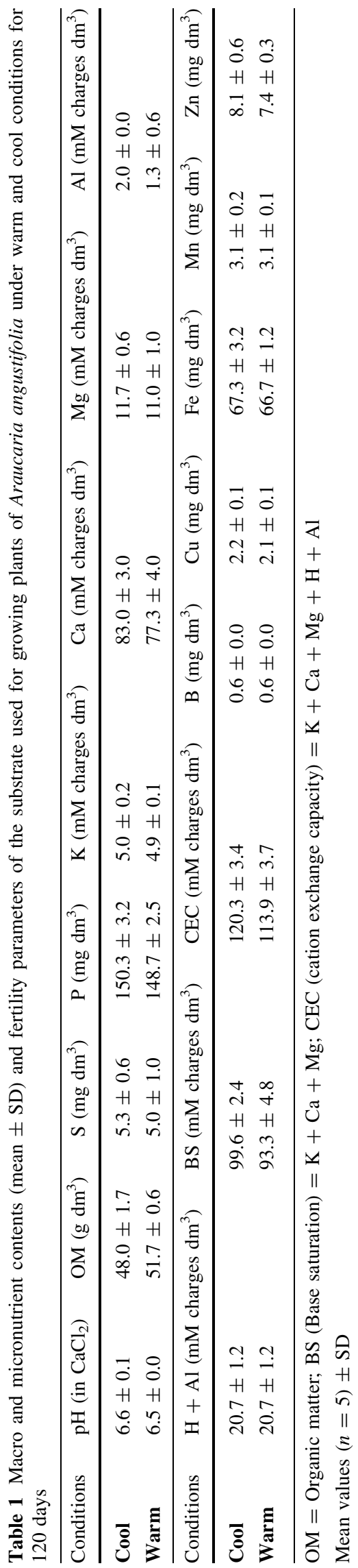


Table 2 Macronutrient contents (mean $\pm \mathrm{SD}$ ) in Araucaria angustifolia growing under warm and cool conditions for 120 days
Fig. $3 \mathrm{CO}_{2}$ assimilation (a) and transpiration (b) rates, intercellular $\mathrm{CO}_{2}$ concentration (c), water use efficiency (d), stomatal conductance (e) and intrinsic water use efficiency (f) in Araucaria angustifolia plants grown in warm and cool conditions. Measurements were taken at 30, 60, 90 and 120 days after the start of treatment application and each symbol represents the mean value of six replications. Vertical bars are standard deviation and different letters indicate difference between both conditions and the absence of letters indicates a lack of difference using the Student $t$ test $(P<0.05)$

Table 3 Two-way analysis of variance of $\mathrm{CO}_{2}$ assimilation rates of A. angustifolia plants grown under warm and cool conditions for 120 days of study

\begin{tabular}{|c|c|c|c|c|c|c|}
\hline & \multicolumn{2}{|l|}{ Roots } & \multicolumn{2}{|l|}{ Shoots } & \multicolumn{2}{|l|}{ Leaves } \\
\hline & Warm & Cool & Warm & Cool & Warm & Cool \\
\hline $\mathrm{N}$ & $11.97 \pm 0.7$ & $11.14 \pm 1.6$ & $5.42 \pm 0.19$ & $4.71 \pm 0.48$ & $13.59 \pm 0.51^{\mathrm{a}}$ & $9.52 \pm 0.20^{b}$ \\
\hline $\mathrm{P}$ & $1.87 \pm 0.49$ & $1.69 \pm 0.2$ & $1.54 \pm 0.34$ & $1.39 \pm 0.16$ & $2.17 \pm 0.51$ & $2.11 \pm 0.34$ \\
\hline K & $7.99 \pm 3.02$ & $6.72 \pm 0.53$ & $11.99 \pm 1.93$ & $11.73 \pm 1.59$ & $13.77 \pm 0.77$ & $12.75 \pm 2.69$ \\
\hline $\mathrm{Ca}$ & $6.02 \pm 1.15$ & $4.42 \pm 0.28$ & $3.20 \pm 0.70$ & $3.25 \pm 0.18$ & $7.38 \pm 0.32$ & $7.43 \pm 0.71$ \\
\hline $\mathrm{Mg}$ & $1.87 \pm 0.40$ & $1.63 \pm 0.06$ & $1.10 \pm 0.17$ & $1.33 \pm 0.12$ & $2.87 \pm 0.21$ & $2.67 \pm 0.68$ \\
\hline S & $1.99 \pm 0.43$ & $1.31 \pm 0.12$ & $0.66 \pm 0.05^{\mathrm{a}}$ & $0.58 \pm 0.01^{\mathrm{b}}$ & $1.34 \pm 0.07$ & $1.56 \pm 0.35$ \\
\hline
\end{tabular}

For each plant organ, distinct letters between warm and cool conditions represent significant differences by Student $t$ test at $5 \%$ probability. Absence of letters indicates a lack of significant differences between warm and cool conditions $(P<0.05)$

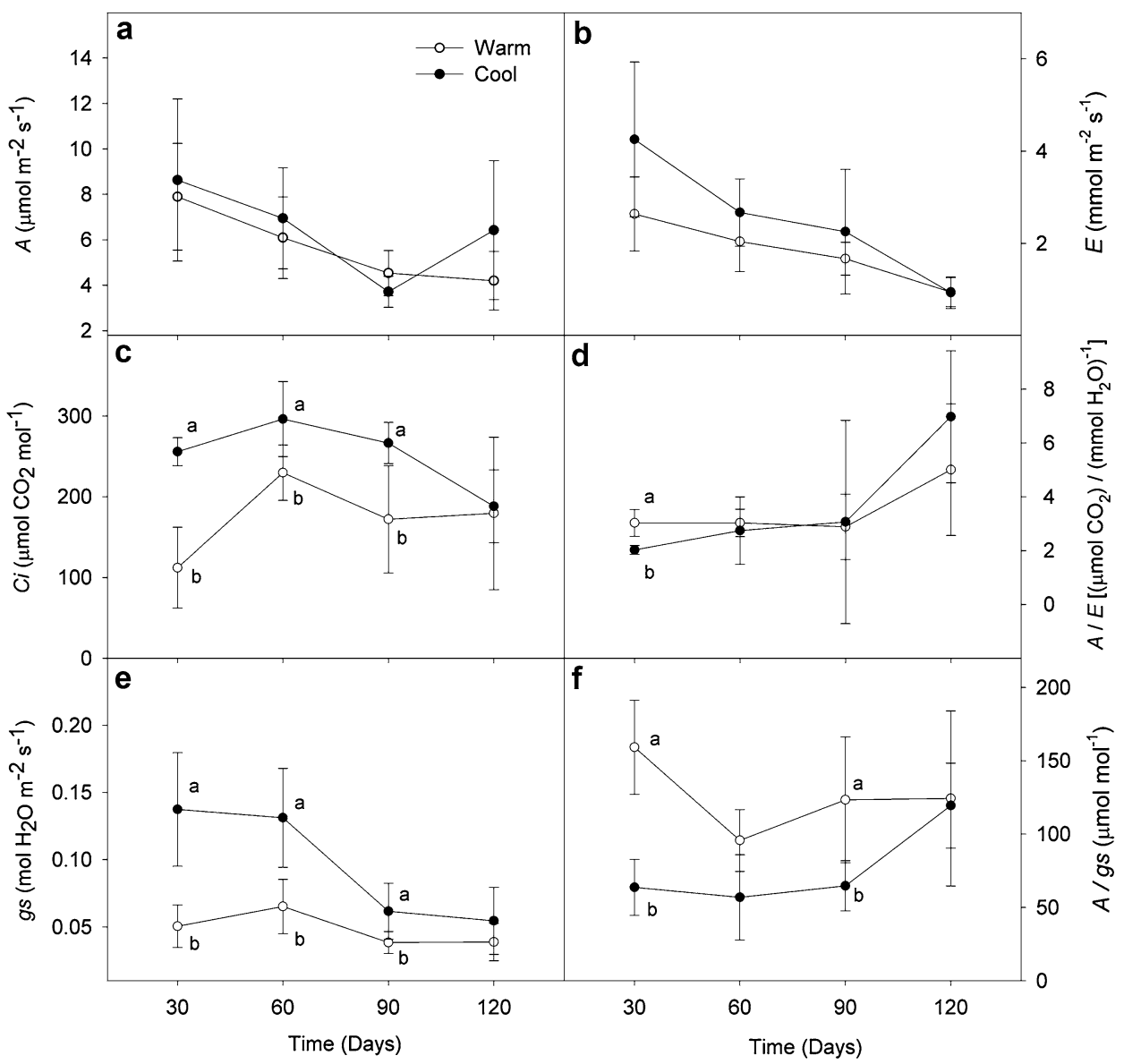

\begin{tabular}{lcccrr}
\hline Source of variation & Degrees of freedom & Square sum & Mean square & $F$ & $P$ \\
\hline Temperature & 1 & 6.717 & 6.717 & 1.384 & 0.246 \\
Time & 3 & 112.199 & 37.400 & 7.708 & $<0.001$ \\
Temperature $\times$ Time & 3 & 14.001 & 4.667 & 0.962 & 0.420 \\
Residual & 40 & 194.075 & 4.852 & & \\
Total & 47 & 326.992 & 6.957 & & \\
\hline
\end{tabular}


Fig. 4 Shoot length (a), root length (b), number of leaves (c), root volume (d), biomass of the whole plant (e), and total leaf area per plant (f) after 120 days of experiment under warm and cool conditions. Vertical bars are standard deviation and different letters are significantly different from each other using the Student $t$ test $(P<0.05)$

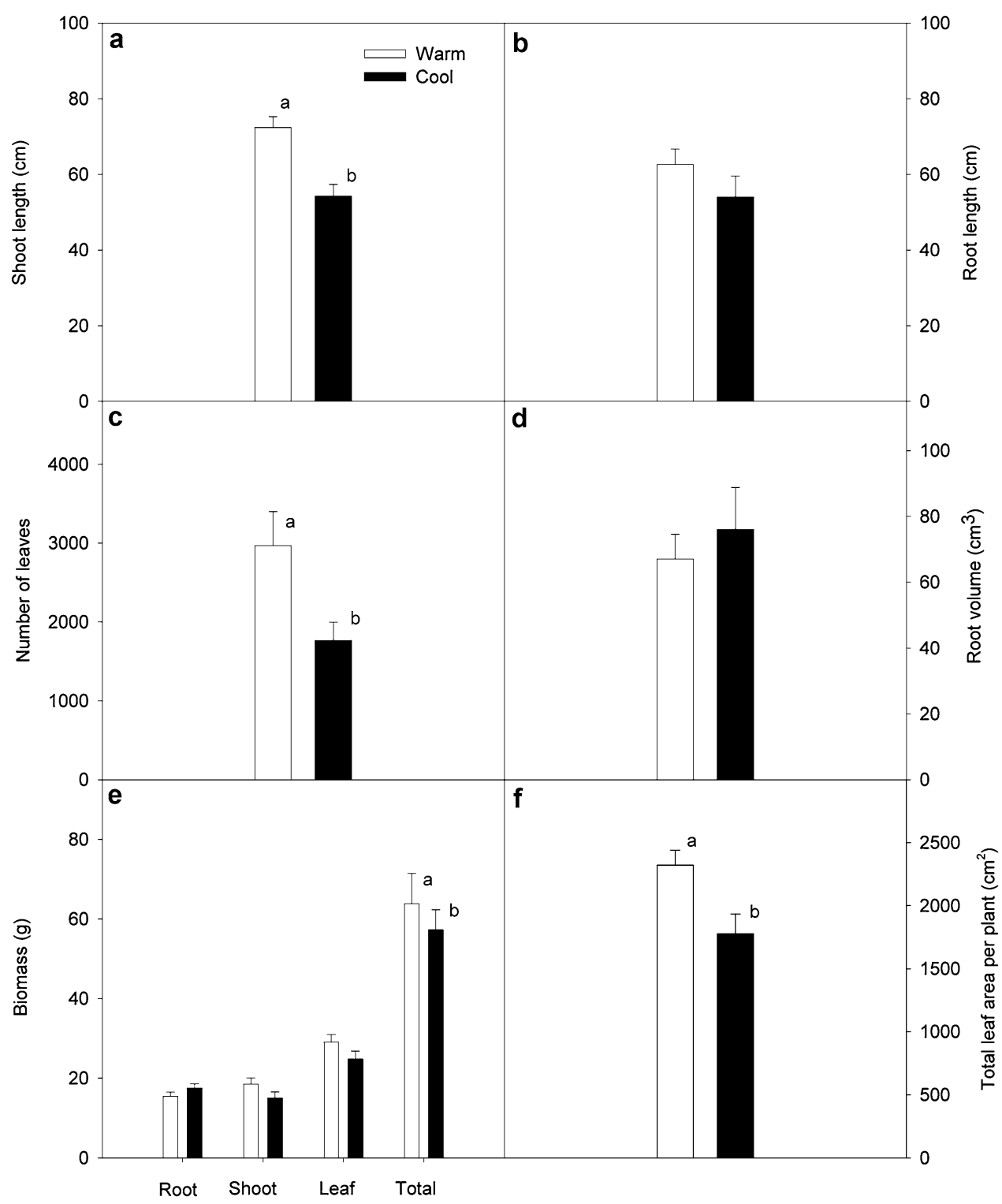

The gain in shoot length was greater in plants under warm conditions when compared to that under cool conditions at every evaluation day (Fig. 5a). The gain in root-collar diameter was the same for plants grown under both conditions (Fig. 5b), while the gain in the number of new shoots was higher for plants under warm conditions when compared to those under cool conditions only at 120 days of experiment (Fig. 5c).

The PNUE of plants under warm conditions was $25 \%$ lower when compared to those under cool conditions (Fig. 6).

\section{Discussion}

Contrary to our hypothesis, the results demonstrate that warm conditions enhance growth in A. angustifolia. Plants, in general, have an optimal as well as minimum and maximal air temperature for vegetative growth (McClung and Davis 2010; Hatfield and Prueger 2015). Although A. angustifolia occurs in high latitudes and/or high altitudes (Franco et al. 2005; Duarte et al. 2006), which reinforces that its growth and success may be associated with low temperatures, there are no studies showing the optimum temperature range for the vegetative growth of this species, making a contrast with studies of seed germination of this species. For seed germination of A. angustifolia, it has been demonstrated that the optimum temperature varies between 20 and $25{ }^{\circ} \mathrm{C}$ (Kissmann and Habermann 2014).

Although the biomass of organs measured at the end of the study showed similar values between plants under both conditions (Fig. 4e), the shoot length (Fig. 4a) and the number of leaves (Fig. 4c) were 25 and $40 \%$ higher in plants under warm conditions than in cool conditions, 


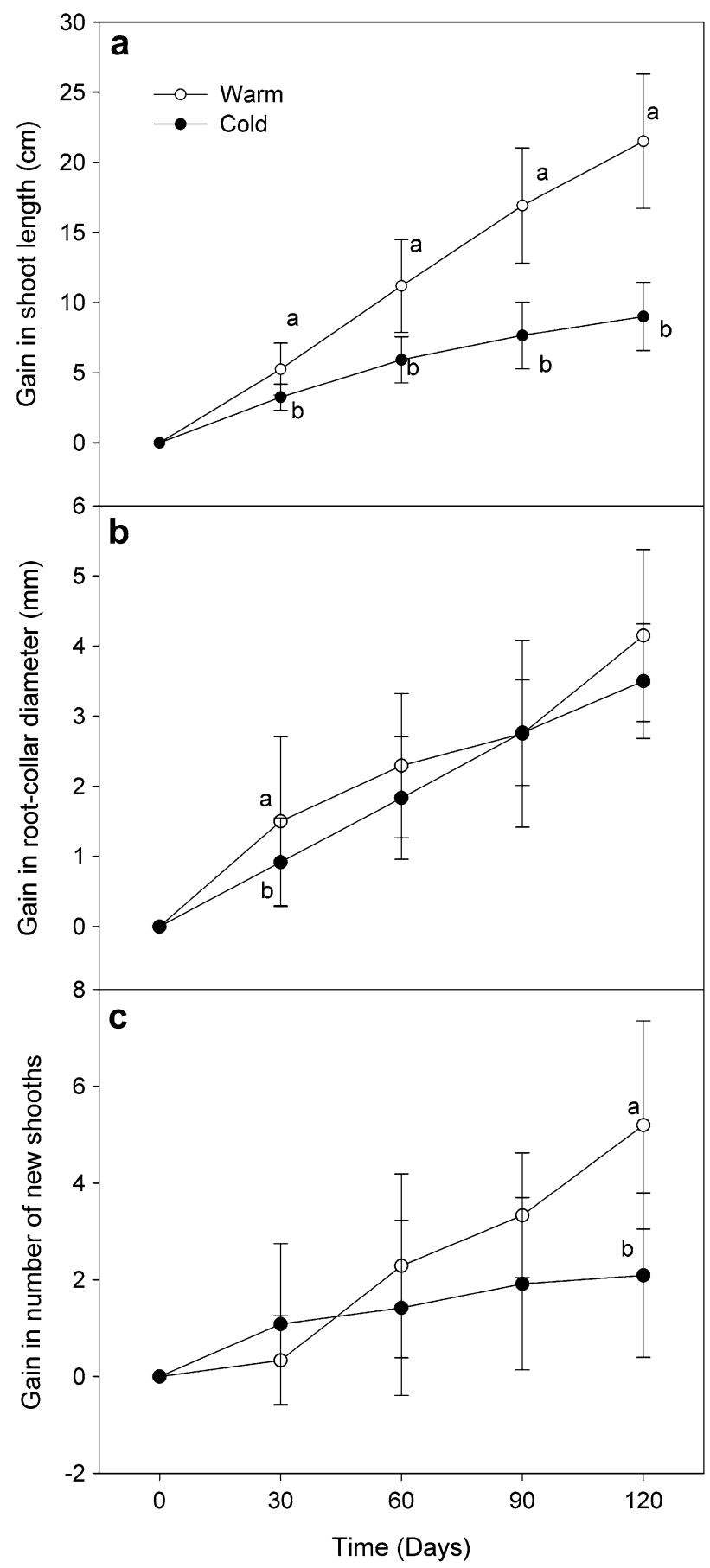

Fig. 5 Gains in shoot length (a), root-collar diameter (b) and number of new shoots (c) in Araucaria angustifolia plants grown in warm and cool conditions. Measurements were taken at 30, 60, 90 and 120 days after the start of treatment application and each symbol represents the mean value of 12 replications. Vertical bars are standard deviation and different letters indicate difference between both conditions and the absence of letters indicates a lack of difference between both conditions using the Student $t$ test $(P<0.05)$

respectively. Temperature rise, in general, may increase stem diameter, plant height, and shoot biomass (Way and Oren 2010). In the present study, the gain in shoot length

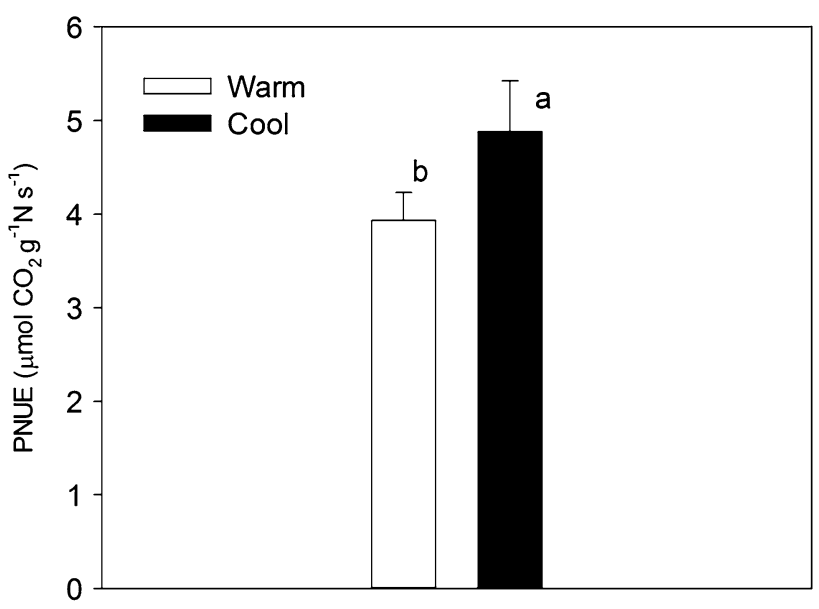

Fig. 6 Photosynthetic nitrogen use efficiency after 120 days of experiment under warm and cool conditions. Vertical bars are standard deviation and different letters indicate difference between both conditions using the Student $t$ test $(P<0.05)$

showed a fivefold increase between 30 and 120 days of experiment for plants under warm conditions, while for plants under cool conditions such increment was only threefold (Fig. 5a). This indicates that under warm conditions, the production of leaves and the shoot apex activity (sink activity) were considerably higher than under cool conditions. Therefore, the present study might be the first report on plant growth of $A$. angustifolia under contrasting temperatures.

In the present study, the temperature in the leaf chamber was similar to growing conditions for the warm treatment; however, the air temperature of $26.8^{\circ} \mathrm{C}$ in the leaf chamber exceeded the temperature at growing conditions for the cool treatment $\left(20 \pm 2.8^{\circ} \mathrm{C}\right.$; Fig. 2$)$. This could have artificially increased $A$ of plants under cool conditions. Nevertheless, carbon assimilation is maintained stable under a $17-34{ }^{\circ} \mathrm{C}$ temperature range when measured in Quercus rubra, Q. falcata, Betula alleghaniensis and Populus grandidentata (Gunderson et al. 2010). For Populus deltoides, increase in temperature results in enhanced plant growth, but has no effect on $A$ (Cerasoli et al. 2014). Therefore, an increment of $6{ }^{\circ} \mathrm{C}$ in the leaf chamber does not seem to influence $A$ of plants grown in cool conditions. Thus, despite growing more under warm conditions, $A$ was the same between plants in both treatments (Fig. 3a), which may refute our prediction that photosynthetic performance of $A$. angustifolia increases under cool conditions, and it deserves further investigation.

The difference in mean temperature between cool and warm conditions was $6{ }^{\circ} \mathrm{C}$, but the amplitude of daily temperature was $3.3{ }^{\circ} \mathrm{C}$ under cool and $14.5{ }^{\circ} \mathrm{C}$ under warm conditions (Fig. 2). Some studies have shown that the amplitude of daily temperature exerts stronger influence on the vegetative growth when compared to the 
influence of daily mean temperature on plant growth (Bueno et al. 2012; Baoguo et al. 2014). For instance, higher vegetative growth and biomass of Populus deltoides (eastern cottonwood) is noted under a $5{ }^{\circ} \mathrm{C}$ amplitude in daily temperature when compared to a constant daily temperature even when under the same daily mean temperature for both conditions (Cerasoli et al. 2014). However, $P$. deltoides is not native to temperate climates, and could benefit from any temperature rise, including the amplitude in daily temperature. When Larix decidua and Pinus mugo, two conifer species, are submitted to constant vs. variable 6 and $12{ }^{\circ} \mathrm{C}$ (minimal and optimum temperatures for both species), these plants show relative insensitivity of growth to the presence or absence of variability in temperature (Hoch and Körner 2009), suggesting that species adapted to cool conditions are not plastic to temperature variability. There are no studies evidencing the minimal, optimum and maximal temperatures for growth of A. angustifolia, and this may be the first study contrasting temperatures for this species. Since all plants within both treatments tested here originated from one population (Pilar do Sul, SP, southeastern Brazil), other provenances of A. angustifolia should be tested under contrasting temperatures. Thus, in the present study, it is possible that $A$. angustifolia might have benefited from the higher amplitude in daily temperature under warm conditions in contrast to the fivefold lower amplitude in daily temperature that occurred under cool conditions, and this topic merits further investigation.

Plants under both conditions showed similar $A$ values over time (Fig. 3a), although plants under warm conditions exhibited higher total biomass (Fig. 4e). This could be due to gas exchange measured at saturating light, while growing conditions provided lower light intensity (Fig. 2b). However, A. angustifolia young plants also grown under $200 \mu \mathrm{mol} \mathrm{m} \mathrm{m}^{-2} \mathrm{~s}^{-1}$ of PPFD exhibited light saturated (at $1000 \mu \mathrm{mol} \mathrm{m} \mathrm{m}^{-2} \mathrm{~s}^{-1}$ of PPFD) $A$ value of $5.4 \pm 1.8 \mu \mathrm{mol}$ $\mathrm{CO}_{2} \mathrm{~m}^{-2} \mathrm{~s}^{-1}$ (Einig et al. 1999), which is similar to $A$ values of plants grown in warm and cool conditions in the present study. Therefore, it is unlikely that gas exchange measurement was biased by different light intensities between growing and measurement conditions. These same authors demonstrated that mature fully developed leaves should be used for measuring gas exchange in this species, as $A$ tend to drop by $50 \%$ in young leaves of A. angustifolia. In the present study we also used mature leaves to assess gas exchange data.

Although plants under cool conditions maintained higher $g s$ values until 90 days of study in relation to plants grown under warm conditions (Fig. 3e), gs did not influence $A$ of any plant group because $A$ was similar between treatments during this period. Cool conditions were provided with an air conditioner, which also dries air.
However, the relative humidity varied by only $5 \%$ in measuring conditions between treatments. In addition, VPD did not seem to influence gas exchange in measuring conditions, as no curve could be regressed between VPD and these rates (see Fig. S1 in supplementary material). For plants under cool conditions, the larger $g s$ for the first 90 days of study did not represent any advantage, such as to increase $A$, although their $C i$ values were higher than those observed in plants under warm conditions for the same period (Fig. 3c). This did not represent any disadvantage either, as it did not allow increased $E$. Nevertheless, plants under warm conditions showed $30 \%$ larger total leaf area per plant (Fig. 4f). Therefore, plants grown in warm conditions can take up more carbon at similar $\mathrm{CO}_{2}$ assimilation rates as plants under cool conditions.

High temperature is also associated with variations in nutrient uptake and usage by the plant. In Pseudotsuga menziesii, a native tree from temperate climates, leaf $\mathrm{N}$ content was lower and plants showed different amino acid groups in a high day/night temperature $\left(30 / 25^{\circ} \mathrm{C}\right)$ when compared to a mild day/night temperature $\left(20 / 30{ }^{\circ} \mathrm{C}\right)$ (Baoguo et al. 2014). In the present study, plants under warm conditions showed almost $30 \%$ more $\mathrm{N}$ in their leaves in comparison to plants grown in cool conditions (Table 2), although both groups of plants grew on substrates with similar fertility (Table 1). This could be associated with the higher growth of plants under warm conditions because tree growth and foliar $\mathrm{N}$ content seem to be positively and linearly associated (Davidson et al. 2007), although these authors used legume and non-legume species in their study. However, although accumulating more $\mathrm{N}$ in their leaves, plants under warm conditions showed a $20 \%$ lower PNUE in relation to plants in cool conditions (Fig. 6). It seems that the uptake of more $\mathrm{N}$ allowed plants under warm conditions to produce more leaves increasing their total leaf area per plant (Fig. 4f), which eventually led to take up more carbon at similar $\mathrm{CO}_{2}$ assimilation rates as plants under cool conditions (Fig. 3a).

Leaves of A. angustifolia are very sclerophyllous. This indicates that these leaves invest less in leaf area and symplastic components and more in thickness and structural components, which requires less $\mathrm{N}$ and results in reduced specific leaf area (leaf area per leaf mass, SLA) (Reich et al. 1998). In fact, most of the $\mathrm{N}$ absorbed by adult and young plants of $A$. angustifolia in the field is metabolized in the roots, suggesting a minor role for $\mathrm{N}$ in shoots and leaves (Franco et al. 2005). Thus, more $\mathrm{N}$ in plants under warm conditions did not directly influence $A$, which was similar between treatments. In addition, it is unlikely that $\mathrm{N}$ was distinctly allocated to photosynthetic (chloroplasts and cytoplasm) or structural (cell walls and fibers) apparatus of A. angustifolia's leaves of plants from any of the conditions because SLA was similar for plants grown in 
both conditions (see Fig. S2 in supplementary material). Therefore, warm conditions enhanced $\mathrm{N}$ uptake and the production of morphologically similar leaves of $A$. angustifolia plants.

One could argue that plants under cool conditions were subjected to $25 \%$ more sunlight when compared to plants under warm conditions, specifically between 10:00 and 16:00 h (Fig. 2b). However, plants under cool conditions grew less than those under warm conditions, indicating that 25\% more PPFD did not make any difference to the performance of these plants. More importantly, it confirms that the temperature contrast was more important than the PPFD difference.

Our results indicate that despite the fact that A. angustifolia can grow more under warm conditions this could not be explained by carbon assimilation rates, which was similar for plants growing under both conditions. Warm conditions enhanced $\mathrm{N}$ uptake and the production of leaves, increasing the total leaf area per plant. This allowed plants grown under warm conditions to take up more carbon at similar $\mathrm{CO}_{2}$ assimilation rates as plants under cool conditions.

Author contribution statement Conceived the idea and designed the experiment: LEC and GH. Performed the experiment: LEC. Analyzed data: LEC, GH and CK. Provided reagents, instruments, material and analytical tools: GH. Wrote the manuscript: LEC, GH and CK.

Acknowledgements Lorena E. de Castro acknowledges the Coordenação de Aperfeiçoamento de Pessoal de Nível Superior (Capes) for a Ph.D. scholarship. C. Kissmann acknowledges the Post-Doctoral program at São Paulo State University (Prope/Unesp, IB Rio Claro). G. Habermann acknowledges the Brazilian National Council for Scientific and Technological Development $(\mathrm{CNPq})$ for a productivity fellowship (Grant 308902/2014-9).

\section{Compliance with ethical standards}

Conflict of interest The authors declare that they have no conflict of interest.

\section{References}

Arroyo MTK, Riveros M, Peñaloza A, Cavieres L, Faggi AM (1996) Phytogeographic relationships and regional richness patterns of the cool temperate rainforest flora of southern South America. In: Lawford RG, Fuentes E, Alaback PB (eds) High-latitude rainforests and associated ecosystems of the west coast of the Americas. Springer, New York, pp 134-172

Atkin OK, Bruhn D, Hurry VM, Tjoelker MG (2005) Evans review no. 2: the hot and the cold: unravelling the variable response of plant respiration to temperature. Funct Plant Biol 32:87-105

Atkin OK, Loveys BR, Atkinson LJ, Pons TL (2006) Phenotypic plasticity and growth temperature: understanding interspecific variability. J Exp Bot 57:267-281

Baoguo D, Kirstin J, Junker LV et al (2014) Elevated temperature differently affects foliar nitrogen partitioning in seedlings of diverse Douglas fir provenances. Tree Physiol 34:1090-1101
Berry J, Bjorkman O (1980) Photosynthetic response and adaptation to temperature in higher plants. Annu. Rev. Plant Phys. 31:491-543

Bueno ACR, Prudente DA, Machado EC, Vasconcelos RR (2012) Daily temperature amplitude affects the vegetative growth and carbon metabolism of orange trees in a rootstock-dependent manner. J Plant Growth Regul 31:309-319

Cassana FF, Dillenburg LR (2013) The periodic wetting of leaves enhances water relations and growth of the long-lived conifer Araucaria angustifolia. Plant Biol. 15:75-83

Cassana FF, Eller CB, Oliveira RS, Dillenburg LR (2015) Effects of soil water availability on foliar water uptake of Araucaria angustifolia. Plant Soil. doi:10.1007/s11104-015-2685-0

Cattaneo N, Pahr N, Fassola H, Leporati J, Bogino S (2013) Sexrelated, growth-climate association of Araucaria angustifolia in the neotropical ombrophilous woodlands of Argentina. Dendrochronologia 31:147-152

Cerasoli S, Wertin T, McGuire MA et al (2014) Poplar saplings exposed to recurring temperature shifts of different amplitude exhibit differences in leaf gas exchange and growth despite equal mean temperature. AoB Plants 6:plu018. doi:10.1093/aobpla/ plu018

Costa e Silva F, Shvaleva A, Broetto F et al (2009) Acclimation to short-term low temperatures in two Eucalyptus globulus clones with contrasting drought resistance. Tree Physiol 29:77-86

Crawford RMM (2008) Cold climate plants in a warmer world. Plant Ecol Divers 1:285-297

Dantas VL, Batalha MA (2011) Vegetation structure: fine scale relationships with soil in a cerrado site. Flora 206:341-346

Davidson EA, Carvalho CJR, Figueira AM et al (2007) Recuperation of nitrogen cycling in Amazonian forests following agricultural abandonment. Nature 447:995-999

Duarte LS, Dillenburg LR (2000) Ecophysiological responses of Araucaria angustifolia (Araucariaceae) seedlings to different irradiance levels. Aust J Bot 48:531-537

Duarte LDS, Dos-Santos MMG, Hartz SM, Pillar VD (2006) Role of nurse plants in Araucaria Forest expansion over grassland in south Brazil. Austral Ecol 31:520-528

Einig W, Mertz A, Hampp R (1999) Growth rate, photosynthetic activity, and leaf development of Brazil pine seedlings (Araucaria angustifolia [Bert.] O. Ktze.). Plant Ecol 143:23-28

Franco AC, Duarte HM, Geßler A et al (2005) In situ measurements of carbon and nitrogen distribution and composition, photochemical efficiency and stable isotope ratios in Araucaria angustifolia. Trees 19:422-430

Gunderson CA, O'Hara KH, Campion CM, Walker AV, Edwards NT (2010) Thermal plasticity of photosynthesis: the role of acclimation in forest responses to a warming climate. Glob Change Biol 16:2272-2286

Hatfield JL, Prueger JH (2015) Temperature extremes: effect on plant growth and development. Weather Clim Extr 10:4-10

Hikosaka K, Ishikawa K, Borjigidai A, Muller O, Onoda Y (2006) Temperature acclimation of photosynthesis: mechanism involved in the changes in temperature dependence of photosynthetic rate. J Exp Bot 57:291-302

Hoch G, Körner C (2009) Growth and carbon relations of tree line forming conifers at constant vs. variable low temperatures. J Ecol 97:57-66

Kissmann C, Habermann G (2014) Different approaches on seed germination to look into global warming effects on Araucaria angustifolia. Theor Exp Plant Physiol 26:39-47

Ledru MP, Stevenson J (2012) The rise and fall of the genus Araucaria: a southern hemisphere climatic connection. In: Haberle SG, David B (eds) Peopled landscapes: archaeological and biogeographic approaches to landscapes. Series: Terra Australis 34. http://www.jstor.org/stable/j.ctt24h85b 
McClung CR, Davis SJ (2010) Ambient thermometers in plants: from physiological outputs towards mechanisms of thermal sensing. Curr Biol 20:R1086-R1092

Mósena M, Dillenburg LR (2004) Early growth of Brazilian pine (Araucaria angustifolia [Bertol.] Kunze) in response to soil compaction and drought. Plant Soil 258:293-306

Raij BV, Andrade JC, Cantarella H, Quaggio JA (2001) Análise química para avaliação da fertilidade de solos tropicais. Campinas, Instituto Agronômico de Campinas (IAC)

Reich PB, Ellsworth DS, Walters MB (1998) Leaf structure (specific leaf area) modulates photosynthesis-nitrogen relations: evidence from within and across species and functional groups. Funct Ecol 12:948-958

Reis MS, Ladio A, Peroni N (2014) Landscapes with Araucaria in South America: evidence for a cultural dimension. Ecol Soc 19:43
Ribeiro RV, Machado EC, Espinoza-Núñez E et al (2012) Moderate warm temperature improves shoot growth, affects carbohydrate status and stimulates photosynthesis of sweet orange plants. Braz J Plant Phys 24:37-46

Sage R, Kubien D (2007) The temperature response of C3 and C4 photosynthesis. Plant Cell Environ 30:1086-1106

Sarruge JR, Haag HP (1974) Análises Químicas em Plantas. Escola Superior de Agricultura Luiz de Queiroz, Piracicaba

Saxe H, Cannell MGR, Johnsen $\varnothing$ (2001) Tree and forest functioning in response to global warming. New Phytol 149:369-400

Way DA, Oren R (2010) Differential responses to changes in growth temperature between trees from different functional groups and biomes: a review and synthesis of data. Tree Physiol 30:669-688

Wrege MS, Higa RCV, Britez MR et al (2009) Climate change and conservation of Araucaria angustifolia in Brazil. Unasylva 60:30-33 